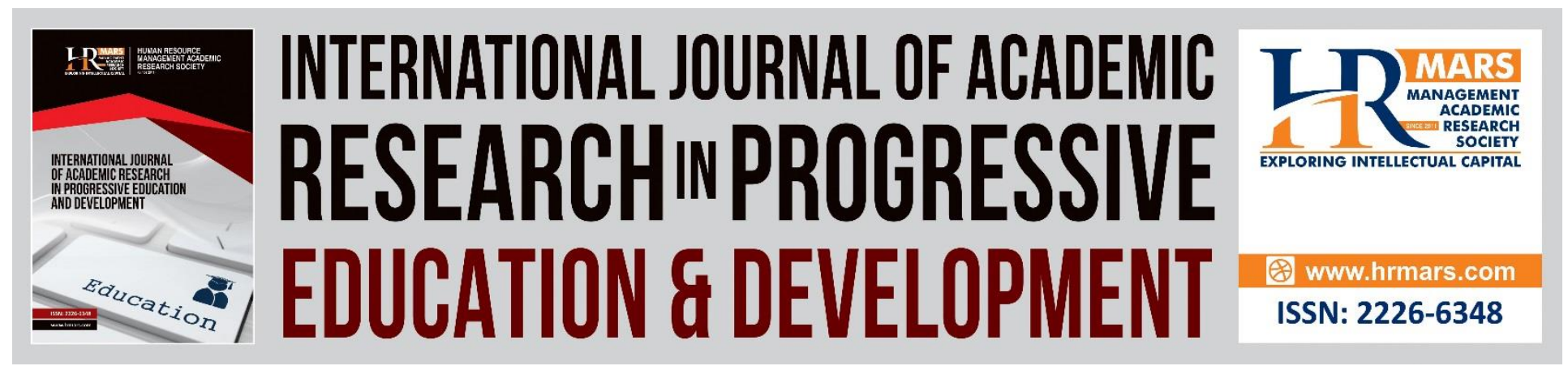

\title{
Construction of Holistic Assessment Standard (Has) for Handball Game Based on Teaching Games for Understanding (TGFU) Teaching Methods
}

Mohamad Asmadi Bin Samdin, Mohd Izwan Bin Shahril, Norkhalid Bin Salimin

To Link this Article: http://dx.doi.org/10.6007/IJARPED/v10-i1/8847

DOI:10.6007/IJARPED/v10-i1/8847

Received: 22 December 2020, Revised: 20 January 2021, Accepted: 07 February 2021

Published Online: 28 February 2021

In-Text Citation: (Samdin et al., 2021)

To Cite this Article: Samdin, M. A. Bin, Shahril, M. I. Bin, \& Salimin, N. Bin. (2021). Construction of Holistic Assessment Standard (Has) for Handball Game Based on Teaching Games for Understanding (TGFU) Teaching Methods. International Journal of Academic Research in Progressive Education and Development, 10(1), 171-186.

Copyright: (C) 2021 The Author(s)

Published by Human Resource Management Academic Research Society (www.hrmars.com)

This article is published under the Creative Commons Attribution (CC BY 4.0) license. Anyone may reproduce, distribute, translate and create derivative works of this article (for both commercial and non-commercial purposes), subject to full attribution to the original publication and authors. The full terms of this license may be seen at: http://creativecommons.org/licences/by/4.0/legalcode

Vol. 10(1) 2021, Pg. 171 - 186

http://hrmars.com/index.php/pages/detail/IJARPED

JOURNAL HOMEPAGE

Full Terms \& Conditions of access and use can be found at http://hrmars.com/index.php/pages/detail/publication-ethics 


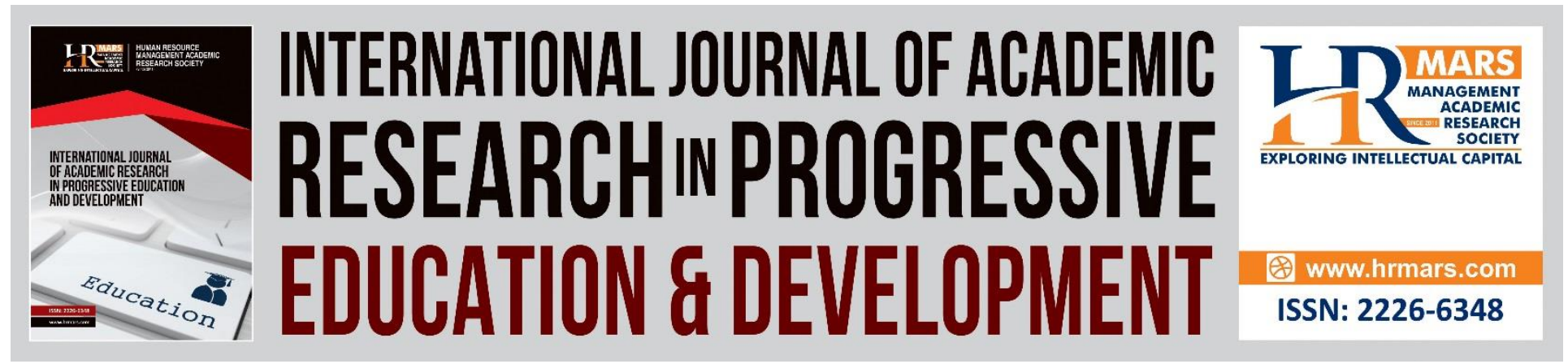

\title{
Construction of Holistic Assessment Standard (Has) for Handball Game Based on Teaching Games for Understanding (TGFU) Teaching Methods
}

\author{
Mohamad Asmadi Bin Samdin, Mohd Izwan Bin Shahril, \\ Norkhalid Bin Salimin \\ Faculty of Sports Science and Coaching, Universiti Pendidikan Sultan Idris, Tanjung Malim, \\ Perak, Malaysia
}

\begin{abstract}
This study aims to build the Holistic Assessment Standard (HAS) instrument for handball games based on the teaching method of Teaching Games for Understanding (TGfU) in Form 2 Physical Education through the Holistic Assessment Standards (HAS) approach. The construction process of the Holistic Assessment Standard (HAS) uses two models as the basis for the process of forming and constructing it, namely Dick \& Carey Model and Morrow Model as well as seven resources to assess the students' mastery and achievements which are the main thrive as a reference in the construction of this instrument, the TGfU Model, Malaysian Education Development Plan Document (PPPM) 2013 - 2025, Relevant Professional Circular Letter, Curriculum and Assessment Standard Document (DSKP) Form 2, Contruktivism Theory, Krathwohl Taxonomy, Bloom \& Masia, and Higher Order Thinking Skills (HOTS). Discussion focuses on the construction of Holistic Assessment Standards (HAS) instruments involving teacher assessment methods through observation and works sheets. The assessment method aims to collect data to measure the level of mastery and achievement of students' learning in terms of psychomotor, cognitive, and affective domains involving two phases i.e. construction phase and instrument effectiveness phase. The design of this study is in the form of pre-experiment methods - a one-time study of cases used for both phases of the study. As a result of this study, the study could produce holistic assessment instruments, user-friendly and able to measure students' differences in terms of mastery and achievement in handball games, in line with the needs of school-based assessment and should be used in the physical education teaching and learning process for form 2 handball games and have an approach as a guide to improving the quality of assessment as desired in the Malaysian Educational Development Plan (PPPM) 2013-2025.

Keywords: Holistic Assessment Standard (HAS), Handball, Teaching Games for Understanding (TGfU)
\end{abstract}




\section{Introduction}

The Ministry of Education Malaysia (MOE) emphasizes the implementation of School-Based Assessment (PBS) towards the incidence of holistic and balanced students. The introduction of School-Based Assessment (PBS) in the new curriculum focuses on assessment for learning as well as enhancing the role of teachers and teaching and learning processes (PDP). The assessment system introduced in the new curriculum gives autonomy to teachers in terms of determining the form of assessment implemented (Malaysian Examination Board [MEB], 2011). Teachers will report on the development of one-page reporting so that all components of PBS can be utilized to guide and expand students' potential.

This assessment format is more holistic, comprehensive, and in line with the curriculum in the form of standard reference. What will be assessment covers the overall level of mastery i.e. covering the psychomotor, cognitive, and affective domains of students collectively and holistically by looking at all aspects during the students' learning process with various methods. Nevertheless, the success of reform in the education system depends on the factor that the teacher carries out the assessment. Changes will not happen if teachers are not convinced about the need to change and are willing to change paradigms (Norazilawati et al., 2012). Teachers need to achieve their goals and objectives in the teaching and learning process so that the level of achievement of its goals and objectives can be seen through the assessment and evaluation process carried out.

According to Hamimah \& Rohaya (2014) stated that in its study there are four main challenges to teachers in implementing SBA i.e. time, teacher competency, teaching and learning facilities, and the SBA management system itself. Teachers are forced to face many challenges and they are in the dilemma of implementing SBA because this assessment transformation requires the willingness of teachers in terms of knowledge of assessment and preparation of instruments, school infrastructure facilities that can support the smooth running of PBS. (Rahman \& Ali, 2008) most teachers are not prepared with alternative assessment assignments such as PBS and who only add teacher tasks and have time constraints especially for students of different levels of ability. Despite being given training and courses, some teachers remain unconvinced in implementing alternative assessments such as confirmation, reliability, practicality, administration, monitoring, and participation. In this regard, how to use or apply assessment information before, during, and after teaching, how to develop appropriate teaching methods according to the assessment results, how to communicate on the results of the assessment (Ramlah et al. 2015).

The assessment of activities in Physical Education (PE) and co-curricular subjects aims to measure the value of performance, participation, and involvement of students in Physical Education activities. Assessment of Physical Education activities must be carried out and evaluated based on certain criteria and procedures (Mosston \& Ashworth, 2008). Assessment is crucial to provide feedback on the level of student achievement as well as the effectiveness of the PDP process conducted by teachers in schools (Mecier \& Doolittle, 2013). For Physical Education subjects the assessment of behavior is ideal for assessing the level of achievement of students who emphasize application assessment and practical in real situations. According to Striggin (1987), a student assignment can be assessed through the method of assessment of 
Vol. 10, No. 1, 2021, E-ISSN: 2226-6348 @ 2021 HRMARS

conduct. This assessment involves the process of observation and judgment of the processes and projects undertaken by the students.

It should be established a standard form of assessment that is capable of evaluating students as a whole and able to focus on the ability of teachers to deliver lessons effectively both inside and outside the classroom (Kementerian Pendidikan Malaysia [KPM], 2012). Therefore, this study proposes the approach and use of Holistic Assessment Standards (HAS) as a standard instrument and following standards and user-friendly in student assessment activities especially in mastering students' knowledge, skills, attitude, and value, in line with the government's desire in PPPM $2013-2015$.

\section{Theoretical Framework}

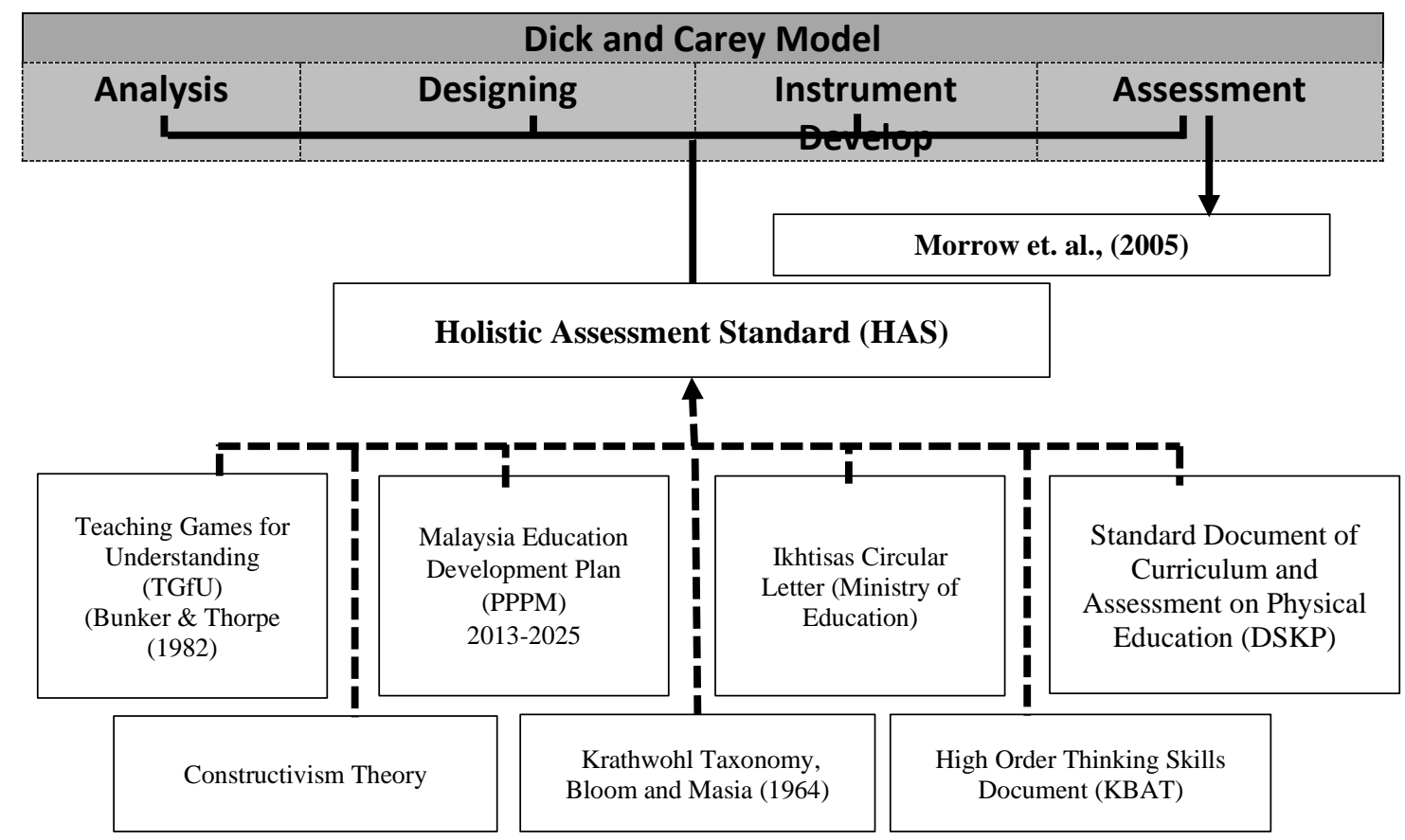

Figure 2.1: Theoretical Framework of the Study

The construction of the Holistic Assessment Standard (HAS) uses two models as a basis in the forming and construction process, namely, the Dick \& Carey Model (Dick, Carey \& Carey, 2001) and the Morrow et al. (2005) as well as seven resources to assess student mastery and achievement which is the mainstay as a reference in the formation of this instrument namely 1 ) TGfU Model (Bunker \& Thorpe, 1986), 2) Malaysian Education Development Plan Document 2013 - 2025, 3) Circular letter Related Professionals, 4) Curriculum and Assessment Standard Document (DSKP) Physical Education and Health Education (PJPK) Form 2, 5) Constructivism Theory, 6) Krathwohl, Bloom \& Masia Taxonomy (1964), 7) High Level Thinking Skills Document ( KBAT). 


\section{Model Dick \& Carey (Dick, Carey \& Carey, 2001)}

Dick \& Carey's models contain components that depend on each other indicated by straight lines and dotted lines. The components contained in this model are adjusted and referenced by the researcher in determining the HAS development process.

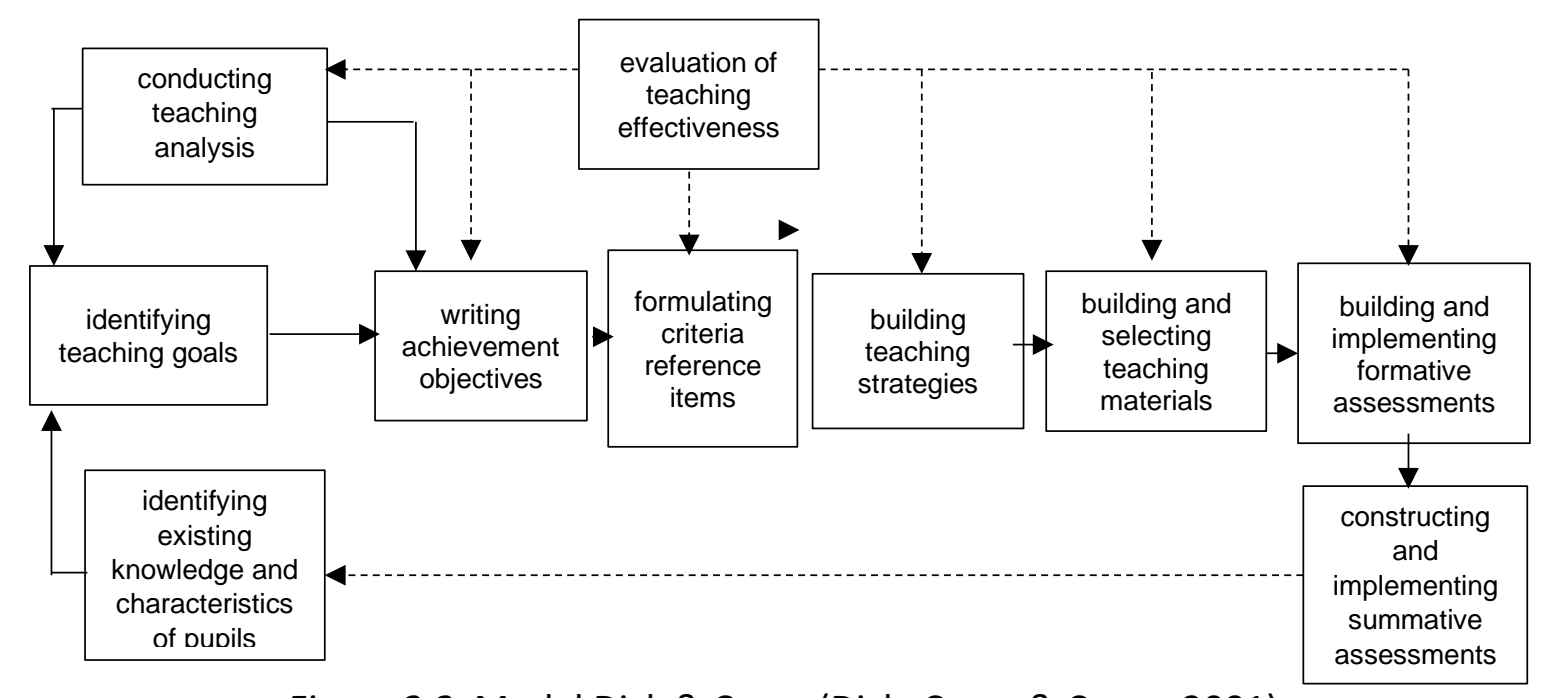

Figure 2.2. Model Dick \& Carey (Dick, Carey \& Carey, 2001)

Figure 2.2 shows the Dick \& Carey Model which contains 10 components namely identifying teaching goals, conducting teaching analysis, identifying existing knowledge and characteristics of pupils, writing achievement objectives, formulating criteria reference items, building teaching strategies, building and selecting teaching materials, building and implementing formative assessments, evaluation of teaching effectiveness, constructing and implementing summative assessments (Dick \& Carey, 1985). The components in Dick \& Carey Models are more complex when compared to other models (Morrison, Ross, \& Kemp, 2001).

This model involves student components, instructors, teaching materials, and teaching environments. Each step in this model receives input from the previous steps that will give output to the next step. Where each component of this model is interconnected, interacting and working together to produce effective outputs to achieve predetermined purposes, as well as able to help repair existing models in the event of any weaknesses (Dick \& Carey, 1996; 2001). However, Ahmad (2003) divided Dick \& Carey Model into four key measures, namely analysis (identifying teaching goals, identify teaching goals, identify existing knowledge and pupils' designs (write achievement objectives, formulate criteria reference items, build teaching strategies, evaluate teaching strategies, evaluation effective teaching), construction (build and select materials) and assessment (build and implement formative assessment, build and implement summative assessment). Researchers feel the Dick \& Carey Model is the most suitable model for underlying the construction of the Holistic Assessment Standards (HAS) in this study. 
INTERNATIONAL JOURNAL OF ACADEMIC RESEARCH IN PROGRESSIVE EDUCATION AND

DEVELOPMENT

Vol. 10, No. 1, 2021, E-ISSN: 2226-6348 @ 2021 HRMARS

Model Morrow et al. (Morrow, Jackson, Disch, \& Mood, 2005)

In addition to the model, Dick \& Carey investigators made the Model Morrow et al, (2005) as a guide during the assessment process of the Instrument Of Holistic Assessment Standard (HAS) as shown in Figure 2.3.

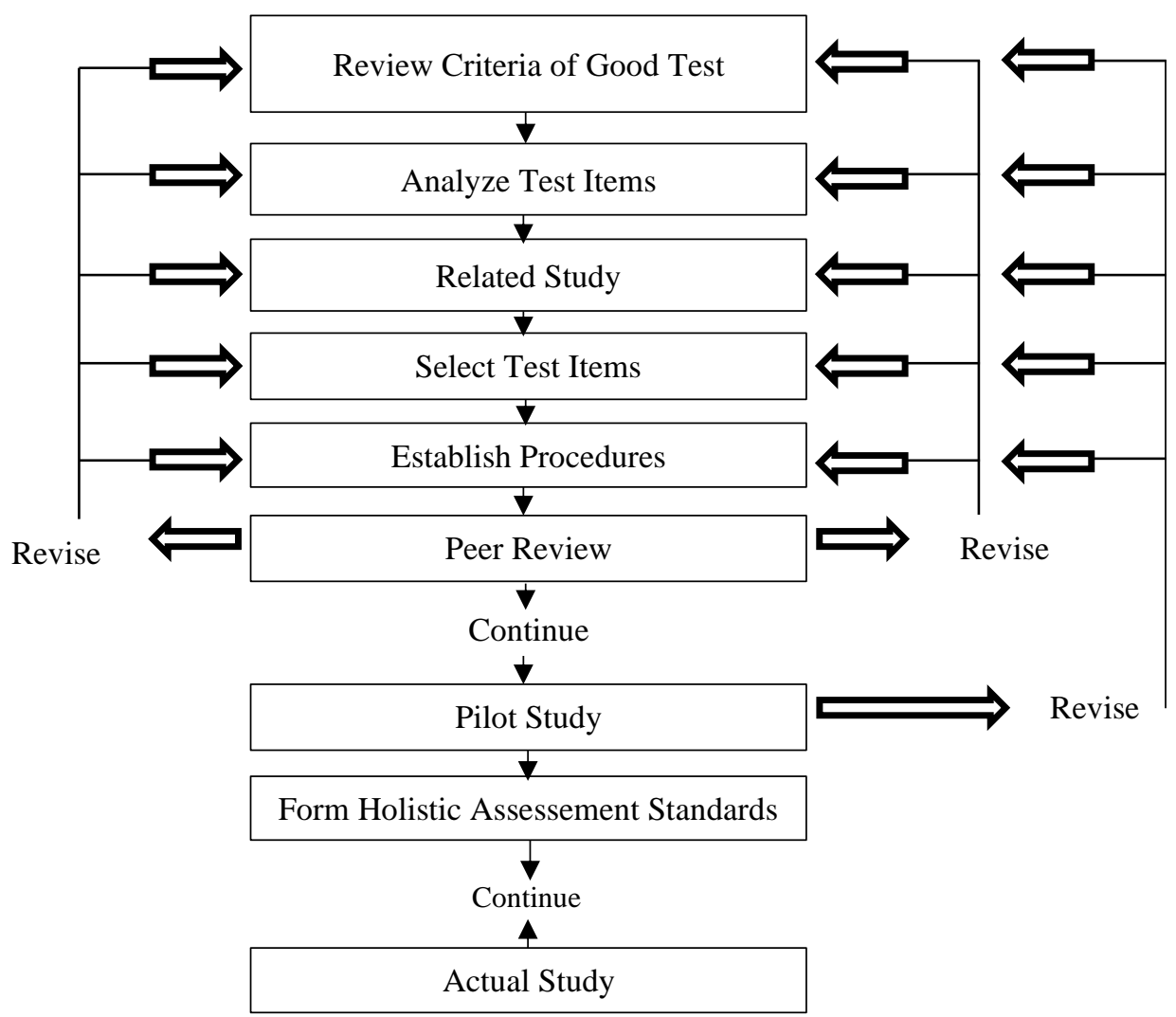

Figure 2.3. Standard Holistic Assessment Standard Instrument Testing Flow Chart (HAS) based on Morrow et al. (2005)

Figure 2.3 shows the Model Morrow et al. (2005) there are nine stages of instrument construction in the flow chart which serves as a guide for researchers i.e. determination of good assessment criteria and objective determination, analyzing the contents of objects/target determination, choosing appropriate assessments and choosing instrument items, setting criteria performance, determining the quality of assessment, referring to experts, pilot studies, forms of assessment and field studies.

\section{Teaching Games for Understanding (Bunker \& Thorpe, 1982)}

The teaching Games for Understanding (TGfU) approach is a teaching approach to understanding games used by teachers in implementing HAS assessment aimed at generating a comprehensive pupil understanding in all aspects of the game as shown in Figure 2.4. 


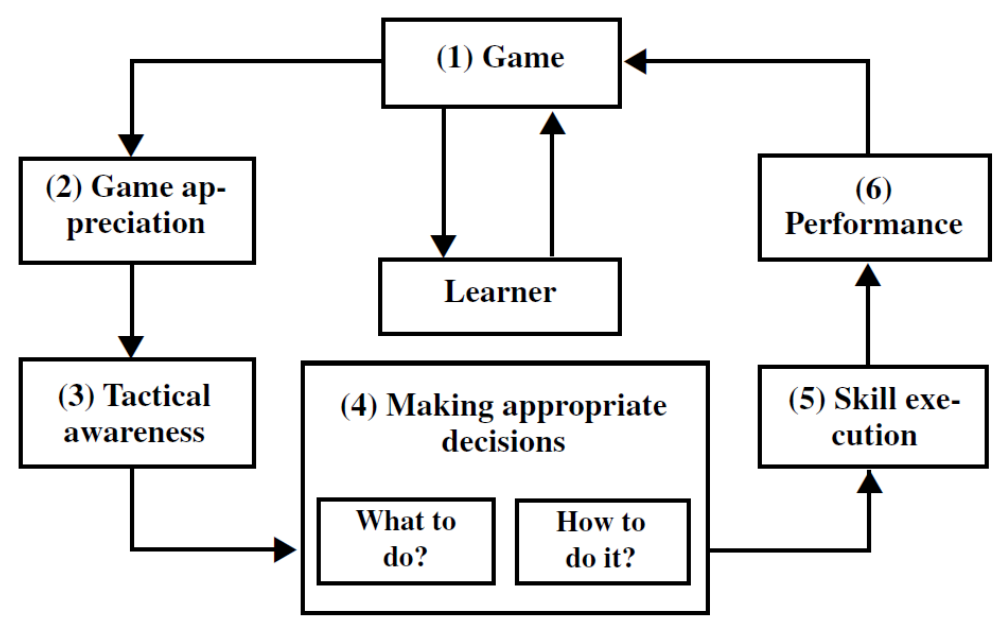

Figure 2.4. Model Teaching Games for Understanding (Bunker dan Thorpe, 1982)

Figure 2.4 shows the Teaching Games for Understanding (TGfU) Model developed by Bunker and Thorpe (1982) is one of the well-known models among educators especially PE subjects (Grifin \& Patton, 2005). TGfU is a model of student-centered game teaching methods for game learning, students will try to develop their problems to acquire skills given the autonomy of thinking by teachers (Richard \& Wallian, 2005). It also focuses on the teaching of tactics and skills in the context of real games. In addition, teachers use the tendencies of games found in pupils to develop skills and tactics in specific games (Bunker \& Thorpe, 1982; Metzler, M. W, 2000).

According to (Gray \& Sproule, 2011) the purpose of this model is how the pupil understands the game through tactical knowledge and ultimately acquires skills. Hopper stressed that TGfU's focus is running from tactics to skills, not tactics or skills. This means pupils will understand the "why" game before "how", therefore, pupils are taught to appreciate the form of more advanced games by joining the refurbished game (Hopper, 2003). McKeen, Webb, and Pearson (2005) found that through the TGfU method pupils can modify games to create fun and expand their creative thinking to create a more meaningful form of the game and create fun while creating opportunities while studying in a conducive and conducive environment.

However, in this TGfU approach, proficiency is taught not in the form of drill training such as traditional teaching which emphasizes the first proficiency approach which is to learn the proficiency of a game before the rules of the game are introduced and emphasize "technical proficiency" (Mitchell et al., 2006). This situation resulted in students making limited decisions (Stolz \& Pill, 2014). There are 6 steps of this teaching model, i.i. the first, the student understands the form and concept of the game. Both students need to know the laws, forms, interests of the game and know how to use the laws of the game. Third, other than this model, based on the principle of pedagogy is to understand the game through tactical knowledge such as the ability to create space and need to be aware of tactical interests (Gray \& Sproule, 2011; Warner, Bunker \& Thorpe, 1996 ). Fourth, students are encouraged to develop their problems through critical thinking skills and autonomy of thinking (Richard \& Wallian 2005). Fifth, students need to be aware of the importance of using appropriate skills in line with the tactics used. Mastery of existing skills will help produce the real movement required in the game situation. Sixth, the student achievement stage can be measured based on the criteria set out in a game following 
that goal by using the steps mentioned above in an attempt to improve achievement in a game situation (Warner, Bunker \& Thorpe, 1996). According to Bunker and Thorpe (1982), the attack category game was chosen because pupils had the opportunity to master a variety of movement skills including sending and receiving the ball using hands, feet, or objects, coordinating handeyes, and clawing opposing teams from controlling the ball by how to dribble, block, intercept or tackle. Hence, the adoption of the Holistic Assessment Standards (HAS) is adapted to the teaching based lessons of the TGfU teaching model so that the implementation of P\&P can effectively measure the achievement and mastery of pupils. The TGfU teaching approach used in the HAS approach is in line with the requirements of DSKP PJPK Form 2 where an emphasis on play and pupils are exposed to tactical problems and strategies in games that are modified to stimulate to make decisions with questions posed by teachers in determining the tactical and strategy to be applied (Bahagian Pembangunan Kurikulum, 2016). The TGfU model cycle is used as the foundation for the construction of the Daily Teaching Plan (RPH) and the implementation of teacher PDP in implementing assessment using the Holistic Assessment Standards (HAS) instrument.

\section{Malaysia Education Development Plan (PPPM) 2013-2025}

The National Education Assessment System (SPPK) is an improved assessment system in the transformation of education through PPPM 2013-2015. One of its transformations is from a system that is domination-oriented and achievement in testing and exams to a more holistic system that gives autonomy to schools implementing assessments. The aim is to provide a set of indicators to assess the potential of pupils and the willingness to learn, in addition to testing the students' mastery and achievements.

Hence, the HAS has made the HAS Assessment Reference Learning Standard in line with PPPM's aspiration to empower formative assessment to provide information on developments to pupils, teachers, and parents through the evaluation process of each domain achievement will provide an overall level of mastery. Assessment results also help teachers assess the teaching methods and activities implemented. In conclusion, HAS can become an assessment instrument to assess the potential of pupils as well as helping PPPM's desire to produce a balanced pupil in various aspects.

\section{Ministry of Education's Ikhtisas Circular Letter}

Refers to Examination Board Circular Letter No. 1 of 2014 dated 31 March 2014 (KPM, 2014) and Earl (2003) state that the assessment of School Assessment (SA) should include assessment for learning, assessment as learning and assessment of learning it can be carried out through observation or monthly testing, term and includes any form of assessment using various instruments such as written assignments, projects, presentations, demonstrations, field studies or case studies.

Hence, the HAS instrument is in the form of SA as the HAS instrument is equipped with a Performance Standard containing six levels of domination so that at the end of the assessment and evaluation process the pupil will gain one of the six levels of overall mastery of the handball game skills. Through the Performance Standards, the achievement and development of students' learning are clearly and holistically inversed. The HAS can be used as an assessment instrument 
following the instructions issued through the professional circular letter as it can serve as an assessment for learning and assessment of learning. The educational assessment instrument used in the game of a sport should be standard and standard (KPM, 2014)

\section{Standard Documents for Curriculum and Assessment of Physical and Health Education (DSKP PJPK)}

Curriculum documents are awakened by the Curriculum Development Division, Ministry of Education Malaysia. This document contains things that should be studied and need to be conveyed and achieved in the process of PDP. Students will be estimated and reported rating the mastery level according to the achievement score based on the learning standards contained in the curriculum document. There are several reasons and objectives of the standard set out in the Kurikulum Standard Sekolah Menengah (KSSM), including ensuring that all pupils adhere to the standards set. Through content standards and learning standards allow teachers to follow guidelines so that students achieve learning objectives more effectively.

Besides, the setting of knowledge, skills, and values that teachers will measure to the students will become clearer. This can be done through the assessment made to pupils. The implementation of the assessment is based on the school. Assessment improvement strategies for assessment for learning can also be identified. According to Veloo (2011), the measurement of pupils' dominance becomes perfect and meaningful if a teacher uses a wide range of test types to achieve a $100 \%$ course score and must use a measurement tool according to the course content. The relationship between PDP's objectives and evaluation is important and interrelated. In this way, teachers and pupils can improve themselves to demonstrate better achievements than prescribed. The school must use DSKP for all subjects including special education provided by Ministry of Education Malaysia (KPM, 2016).

Hence, HAS assessment items are directly implemented to Learning Standards as at the end of the assessment of students should master all the prescribed Learning Standards based on the Performance Standards built.

\section{Constructivism Learning Theory}

Constructivism is the view that pupils actively build their knowledge or concepts based on existing knowledge and experience. Pupils will adapt the knowledge received with existing knowledge to build new knowledge (Pusat Perkembangan Kurikulum, 2001). In PJ, the theory of learning constructivism encompasses two aspects of cognitive and psychomotor. Where pupils need cognitive processing to do something of psychomotor skills (Griffin et al., 1997).

The concept of learning that underlies constructivism's approach to teaching and learning is contextual learning. Contextual learning is a learning activity that combines the content of the lesson with the daily experience of the student in the environment. This type of lesson provides concrete learning that requires hand activities.

\section{Taksonomi Krathwol, Bloom \& Farmhouse (1964)}

Krathwohl et. al., (1964) classifies the affective domain into five levels of taxonomy, i.e. receiving, responding, values, evaluating, sorting, and characterized by values. The affective domain involves spiritual aspects by focusing on the growth and development of attitudes, feelings, 
emotions, and values. Where things are learned and will grow over time. The influence of the environment is very important in influencing such feelings, attitudes, and values and if the environment is healthy, then the feelings, attitudes, and values fostered will be positive (Abu Bakar, 1985). In terms of assessment of pupils in the game, the effective assessment involves the fair value of the game which consists of two sub-values that comply with the rules and comply with the laws of the game. The aspect of value in badminton games is the spirit of sportsmanship consisting of two sub-values i.e. receiving loss and respect for the opponents (Salimin et al., 2015).

The study, conducted by Shen, (2014) found physical activity outside the schoolroom could provide students with extensive cognitive and effective foundations and influence their motivation in Physical Education (PE). Teachers understand the importance of the affective domain for the growth and development of pupils, therefore teachers assess the effective behavior of pupils by documenting them. The study used self-determination and hierarchy motivation models conducted in the United States with a sample of 545 male and female students of Physical Education.

According to Taber (2015), Krathwol Taxonomy, which was inspired in 1964, divides the affective domain into five stages of accepting, appreciating, organizing, and fostering characterization. The affective domain is a strategy of morals formation that emphasizes the formation of students' personalities through faith and morals. However, most PJ teachers often ignore the interest of affective domain in physical education PDP. The difficulty in assessing this domain is among the reasons most PE teachers fail to carry out affective domain assessments (McLeod, 1991; Tittle \& Hecht, 1989). Supposedly, affective domains are important domains that should be given attention and assessed by PJ teachers in the Physical Education PDP session (Salimin et al., 2013).

Thus, Krathwohl et al., (1964) was made one of the main thumbnails in the formation of Holistic Assessment Standards to ensure pupils are evaluated in terms of effective domains involving spiritual aspects with emphasis on growth and development of attitudes, feelings, emotions, and values. Through the effective aspects of pupils can strengthen practice in Physical education through elements of safety, sociological and psychological concepts, principles, and strategies to effectively carry out physical activity involve i) management and safety, ii) selfresponsibility, iii) social interaction, v) dynamics group and, v) ethics in sports.

Thus, this content is included continuously in the HAS instrument in the form of assessment items that need to be assessed based on five achievement scores for affective domain aspect assessment.

\section{Higher Order Thinking Skills (HOTS)}

Critical thinking skills have long been focused on the education system in Malaysia since the 90s. Through the Ministry of Education Malaysia, HOTS has established HOTS as part of its skills based on knowledge acquisition and skills in each subject (Som, 2003). Hence, the HOTS elements included in the assessment can improve high-level thinking skills among students and able to test the ability of pupils to apply knowledge, skills, and values in making cultivation and reflection to solve problems, make decisions, innovate, and create something (KPM, 2013). 
Besides that, the implementation of HOTS in TGfU teaching activities is a method or way to solve problems effectively. According to Lynda Wee (2004) in her book entitled "Jump Start Authentic Problem- Based Learning" Problem-based Learning is an approach to students' destruction and is an effective approach in improving the quality of learning, promoting active engagement of pupils, cooperation, giving quick feedback to the learning process, deep understanding of the subject and referring to students' active involvement. Pupils need to identify problems, define problems, collect information, identify solutions, evaluate each problem solving, make formulations and make informed decisions. The implementation of HOTS in the teaching of TGfU implemented by teachers can enhance the capabilities and capabilities of the students.

Thus, the HOTS element is explicitly included in the DSKP together with 21st Century learning aimed at stimulating structured thinking and focusing among students. HOTS focuses on the four stages of thought which are applying, an analysis, assessing, and creating (Curriculum Development Division, 2016). An effective way to implement HOTS is to raise questions about HOTS during the PDP process. HOTS elements explicitly inputted in HAS are able to measure students' abilities especially in terms of cognitive achievement.

Hence, the HOTS element in HAS has instilled in the construction of a pupil works sheet question which includes the top four levels in the Bloom Taxonomy (Anderson et al. 2001).

\section{Methodology}

Construction of HAS Instruments contains two phases of the construction of instruments and designs at the effectiveness phase of the instrument. The design in this study also contains two namely designs at the instrument construction phase and design at the effectiveness phase of the instrument.

The design of the study at the construction phase of the instrument and the effective phase of the HAS instruments is using the pre-experiment method - a one-time case study (OneShot Case Study), which means that no control group is done on the study group (Gay, Mills and Airasian, 2006). Only involved a group of studies disclosed to treatment (X) and post-testing (O). Its purpose is to determine the impact and changes in lean variables. Studiers studied and observed the study group only once (Konting, 2000). This design is suitable for use by (Liza, 2017; Hanapiah, 2019; Mohd Izwan, 2017; Norkhalid, 2012)

The study of the construction of the HAS contains the assessment of handball games based on the Standard Document of The Assessment curriculum for Physical Education and Health Education (DSKP). It will measure the overall level of mastery and students' achievements for the psychomotor, cognitive, and affective domain aspects that only use the method of obtaining scores of students' achievement level in learning skills through observation and worksheets. Besides, the teacher's level of reflection on the use of Holistic Assessment Standards (HAS) was used to obtain data on teacher reflection level.

The design of the study in the effectiveness phase of the study referred to a group of teachers who were the subject of study using two types of instruments namely Holistic Assessment Standards (HAS) and Game Performance Assessment Instrument (GPAI) developed by Mitchell et al., (2006) used as a study instrument. The use of HAS and GPAl instruments is used against the samples of Form 2 Physical Education pupils. 
Vol. 10, No. 1, 2021, E-ISSN: 2226-6348 @ 2021 HRMARS

i. Instrument Construction Phase

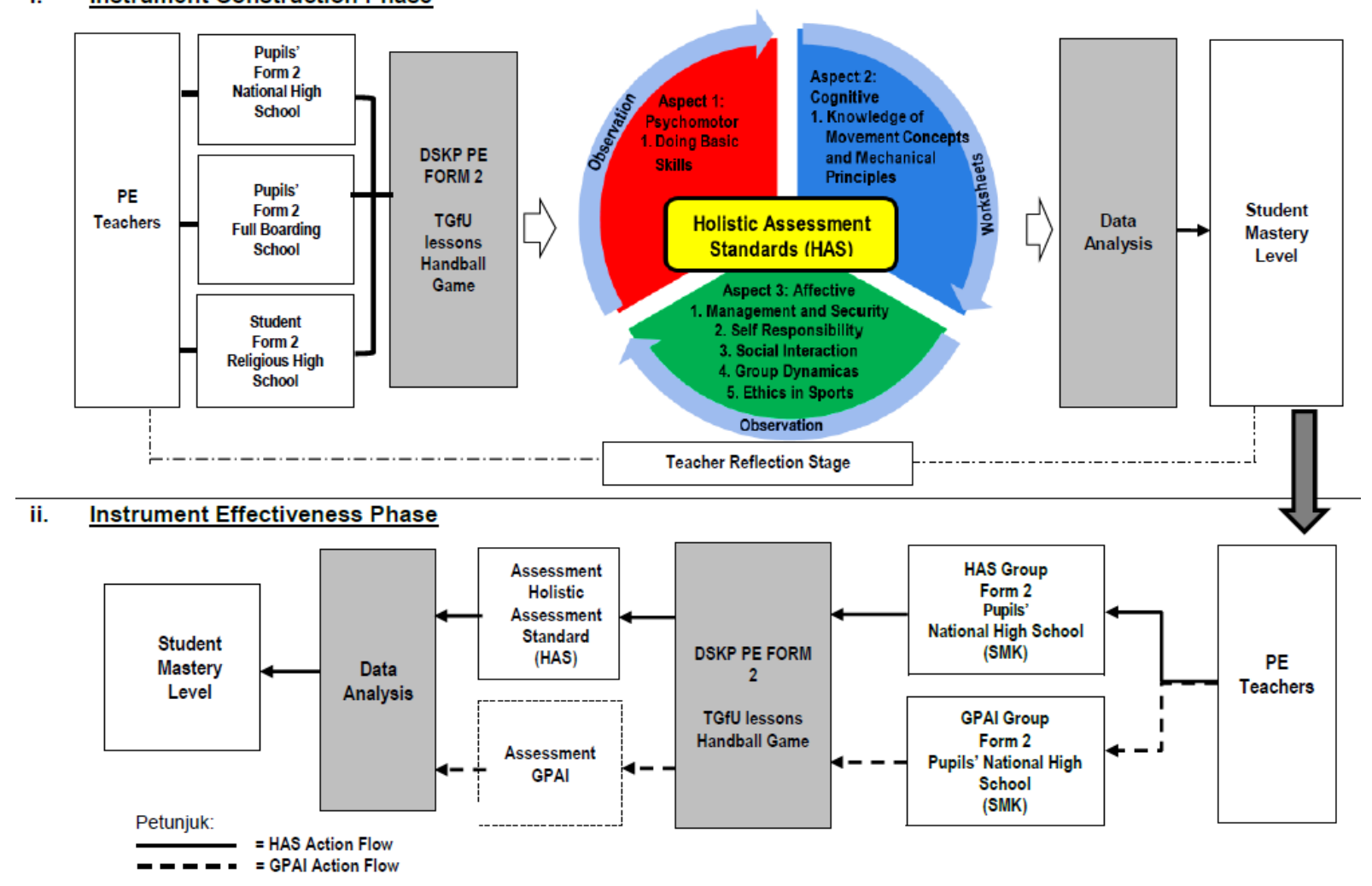

Figure 3.1. Conceptual Framework

\section{Discussions}

The Holistic Assessment Standards (HAS) produced are ideal for teachers to obtain information on the level of students' mastery and the progress of the teaching process for PE subjects. Therefore, the results of the assessment obtained can be used by the teacher to determine whether the skills taught were successfully mastered or not by pupils. Also, teachers can identify students' achievements in terms of psychomotor, cognitively, effectively. Indirectly, the implementation of Physical Education subjects will be more effective as students can know the level of self-achievement in terms of psychomotor, cognitive, effective.

\section{Conclusion}

Based on the findings of the study, the HAS instrument is a standard assessment instrument to assess the level of mastery of students for the form 2 handball game. Through the reported mastery results, students have the opportunity to identify their strengths and weaknesses. In line with the new narrative of educational practice in Malaysia which is focused on student-oriented learning-oriented learning. In addition, HAS is a holistic, user-friendly assessment instrument and can measure student differences in terms of mastery and achievement in the game of handball, in line with the needs of school-based assessment as intended in the Malaysian Education Development Plan (PPPM) 2013-2025.

Construction of HAS instruments embodied in fulfilling the purpose of assessment, namely assessment as feedback. Teachers test students' knowledge, understanding, and skills in 
response to the effectiveness of teacher teaching. It is in the formative form used throughout the PDP process and ensures the students' understanding of the PDP planned by the teacher. In conclusion, assessment is used as a self-check that students make a reflection of their own mastery to improve their learning, which in turn, can reflect the belief that all students can improve their abilities. In addition, assessment as evidence occurs when the teacher uses the teacher's evidence to make judgments on student mastery. It can show the accountability and accountability of the school to the community when student mastery is reported.

\section{Suggestions}

The construction of HAS is a study related to learning assessment instruments using TGfU teaching methods as an intervention to studies that can improve students' mastery of game skills. Therefore, it is proposed that the construction of assessment instruments with the concept of complete-game skills should be implemented. The concept of skills contained in DSKP PE subjects such as rugby, football, hockey, and other sports should be studied its builders. It can be used as a guide for teachers in implementing classroom assessment more effectively.

\section{Reference}

Abu Bakar, N. (1985). Penilaian afektif. Masa Enterprise. Jaya: Longman Malaysia Sdn. Bhd.

Adam, A. (2013). The position of team sports in high school. Ranged, 10, 16-21.

Ahmad, H. (2003). Penggunaan Pembelajaran Berbantukan Komputer Mata Pelajaran Asas Perakaunan (H1002) (Doctoral dissertation, Kolej Universiti Teknologi Tun Hussein Onn Malaysia).

Anderson, L. W., Krathwohl, D. R., Airasian, P. W., Cruikshank, K. A., Mayer, R. E., Pintrich, P. R., James, R., Wittrock, M. C. (2001) A taxonomy for learning, teaching and assessing: $A$ revision of Bloom's taxonomy of educational objectives. Longman.

Bahagian Pembangunan Kurikulum. (2016). Dokumen Standard Kurikulum dan Pentaksiran: Pendidikan Jasmani dan Pendidikan Kesihatan Tingkatan 2. Kementerian Pendidikan Malaysia.

Bauersfeld, H. (1995). The Structuring of the Structures: Development and Function of Mathematizing as a Social Practice. In: L. P. Steffe and J. Gale (Eds.), Constructivism in Education (pages 137-158). Lawrence Erlbaum Associates Publishers.

Bunker, D., \& Thorpe, R. (1982). A model for teaching games in secondary schools. Bulletin of Physical Education, 18, 5-8.

Bunker, B., \& Thorpe, R. (1986). The curriculum model. In R. Thorpe, Bunker, D., \& Almond, L (Ed.), Rethinking games teaching (pp. 7-10). University of Technology, Loughborough.

Dick, W., \& Carrey, L. (1985). The Systematic Design Instruction. Second edition. Scott, Foreman and Company

Dick, W., Carey, L., \& Carey, J. O., (2001). The systematic design of instruction (5th ed.). AddisonWesley, Longman.

Duffy, T. M., \& Jonassen, D. H. (1991). Constructivism: new implications for instructional technology. Educational Technology, May 1991, p. 7-12.

Etemi, F. Z. (2011). Supporting and Developing the Structures for the Quality Assurance at the Private Higher Education Providers. Kosova Accereditation Agency 
Gay, L. R., Mills, G. E., \& Airasian, P. (2006). Educational Research: Competencies for Analysis and Applications. Merrill Greenwood.

Griffin, L. L., \& Patton, K. (2005). Two decades of teaching games for understanding: Looking at past, present and future. In L. Griffin \& J. Butler (Eds.), Teaching games for understanding: Theory, research, and practice (pp. 1-17). Champaign, IL: Human Kinetics.

Griffin, L. L., Mitchell, S. A., \& Oslin, J. L. (1997). Teaching sports concepts and skill: A tactical games approach. Champaign, IL: Human Kinetics.

Gray, S., \& Sproule, J. (2011). Developing pupils' performance in team invasion games. Physical Education and Sport Pedagogy. https://doi.org/10.1080/17408980903535792

Hamimah A. N., \& Rohaya, T. (2014) Cabaran pentaksiran berasaskan sekolah: dilema guru. Prosiding Seminar Antarabangsa Kelestarian Insan 2014., 9 - 102014.

Hopper, T. (2003). Teaching games for understanding: The importance of student emphasis over content emphasis. JOPERD, 73(7), 44-48.

Howey, K. R. (1998). Introduction to the commissioned papers. In Contextual teaching and learning: Preparing teachers to enhance student success in the workplace and beyond. Columbus, OH: ERIC Clearinghouse on Adult, Career, and Vocational Education, Center on Education and Training for Employment and Washington, DC: ERIC Clearinghouse on Teaching and Teacher Education, American Association of Colleges for Teacher Education.

Kementerian Pendidikan Malaysia. (2013). Pelan Pembangunan Pendidikan Malaysia 2013-2025: Pendidikan Prasekolah hingga Lepas Menengah. Kementerian Pendidikan Malaysia.

Kementerian Pendidikan Malaysia. (2014). Pelan Pembangunan Profesionalisme Berterusan (PPB) (Guru dan Pemimpin Sekolah). Bahagian Pendidikan Guru, Kementerian Pendidikan Malaysia.

Kirk, D., \& McPhail, A. (2002). Teaching Games for Understanding and Situated Learning: Rethinking the Bunker-Thorpe Model. Journal of Teaching in Physical Education, 21, 177192.

Konting, M. M. (2000). Kaedah penyelidikan pendidikan. Kuala Lumpur: Dewan Bahasa dan Pustaka

Krathwohl, D. R., Bloom, B. S., \& Masia, B. B. (1964). Taxonomy of educational objectives the classification of educational goals, handbook II: Affective domain. David McKay Company, Inc.

Lembaga Peperiksaan Kementerian Pelajaran Malaysia. (2011). Buku Panduan Pengurusan dan Pengendalian Pentaksiran Berasaskan Sekolah (PBS), Sekolah Rendah. Kementerian Pendidikan Malaysia

Liza, S. (2017) Pentaksiran pembelajaran kemahiran asas bagi permainan kategori serangan dalam Pendidikan Jasmani tahun 4. (Doctoral dissertation, Universiti Pendidikan Sultan Idris).

Lynda, W. (2004). "Jump Start Authentic Problem Based Learning." Prentice Hall. Inc

Mercier, K. \& Doolittle, S. (2013): Assessing Student Achievement in Physical Education for Teacher Evaluation, Journal of Physical Education, Recreation \& Dance, 84:3, 38-42

McKeen, K., Webb, P., \& Pearson, P. (2005). Promoting physical activity through teaching games for understanding in undergraduate teacher education. AISEP, 2005 World Congress Proceedings. Active Lifestyles. The Impact of Education and Sport, 251-258. 
Mitchell, S. A., Griffin, L. L., \& Oslin, J. L. (2006). Teaching sports skills: A tactical games approach (2nd ed.). Champaign, IL: Human Kinetics.

Hanapiah, M. K. (2019). Keberkesanan Pentaksiran Ekstensif (PE) Bagi Permainan Kategori Memadang dalam Pendidikan Jasmani Tahun 5. (Doctoral dissertation, Universiti Pendidikan Sultan Idris).

Izwan, M. S. (2017). Keberkesanan Instrumen Pentaksiran (IPP) Berasaskan Teaching Games for Understanding (TGFU) Bagi Permainan Badminton. (Doctoral dissertation, Universiti Pendidikan Sultan Idris).

Mosston, M., \& Ashworth, S. (2008). In Teaching Physical Education (1st online ed.). Retrieved from http://www.spectrumofteachingstyles. org/ ebook

Morrow, J. R., Jackson, A. W., Disch, J. G., \& Mood, D. P. (2005). Measurement and evaluation in human performance (3rd ed.). Champaign, IL: Human Kinetics.

Morrison, G. R., Ross, S. M., Kemp, J. E. (2001). Designing effective instruction (3 ${ }^{\text {rd }}$ ed.) John Wiley \& Sons.

Norkhalid, S. (2012). Pentaksiran Komprehensif Berbanding Penilaian Kendiri Sekolah Mengah Dalam Mata Pelajaran Pendidikan Jasmani Tingkatan 2. (Doctoral dissertation, Universiti Pendidikan Sultan Idris).

Norazilawati, A., Nik, A., Rosnidar, M. (2012). Pelaksanaan Pendekatan Konstruktivisme Dalam Mata Pelajaran Sains. Universiti Pendidikan Sultan Idris. Jurnal Pendidikan Sains and Matematik Malaysia, 2(1):78-91.

Piaget, J. (1973). The child and reality (A. Rosin, Trans.). Grossman

Pusat Perkembangan Kurikulum (2001). Huraian sukatan pelajaran bersepadu sekolah menengah: Pendidikan jasmani. Kementerian Pendidikan Malaysia.

Rahman, M. A. B. A., \& Ali, Z. B. (2008). Perlaksanaan Pentaksiran Kerja Kursus Kemahiran Hidup Bersepadu Di Sekolah Menengah Luar Bandar Daerah Kuantan, Pahang. http://eprints.utm.my/10757/1

Ramlah A. K, Jamil, A., \& Analisa, H. (2015). Pembentukan Sikap Positif Guru Terhadap Pelaksanaan Aktiviti Pentaksiran. Journal of Personalized Learning 1(1):77-84

Richard, J. F., \& Wallian, N. (2005). Emphasizing students' engagement in construction of game performance. In L. Griffin \& J. Butler (Eds.), Teaching games for understanding: Theory, research and practice (pp. 19-32). Champaign, IL: Human Kinetics.

Salimin, N., Jani, J., Rahmat, A., Haziyanti, N., Khalid, M., Pendidikan, U., Komprehensif, M. P. (2013). Modul Penilaian Komprehensif Bagi Pertolongan Cemas Dalam Pendidikan Jasmani Dan Kesihatan (Comprehensive Assessment Module for First Aids in Physical Education and Health). Asia Pacific Journal of Educators and Education, 28, 155-171.

Salimin, N., Jani, J., Shahril, M. I., \& Elumalai, G. (2015). Validity and reliability of comprehensive assessment instruments for handball and badminton games in physical education. Asian Social Science, 11(23), 12-21.

Shen, B. (2014). Outside-school physical activity participation and motivation in physical education. British Journal of Educational Psychology, 84(1), 40-57. https://doi.org/10.1111/bjep.12004

Som, N., \& Mohd, D. A. R. (1998). Kemahiran Berfikir Secara Kritis dan Kreatif (KBKK). Pearson Malaysia Sdn. Bhd. 
Sulaiman, K. P., Abu Bakar. (1999). Kajian Mengenai Kemahiran Proses Sains di Sekolah Rendah. (Unpublished doctoral). Universiti Teknologi Malaysia.

Soon, S. M. (2004). Ilmu Pendidikan untuk KPLI. Terbitan Ketiga. Kumpulan Budiman Sdn Bhd,

Soon, S. M. (2006). Nota Pengurusan Pengajaran-Pembelajaran. Multimedia-ES Resources Sdn Bhd

Stolz, S., Pill, S. (2014) Teaching Games and Sport for Understanding: Exploring and Reconsidering its Relevance in Physical Education. EPER, 2014; 20: 36-71.Samdin, M. A. Bin, Shahril, M. I. Bin, \& Salimin, N. Bin. (2021). Construction of Holistic Assessment Standard (Has) for Handball Game Based on Teaching Games for Understanding (TGFU) Teaching Methods. International Journal of Academic Research in Progressive Education and Development, 10(1), 171-186.

Veloo, A. (2011) Keupayaan teori dan pelaksanaan pentaksiran dalam pembelajaran. Journal of Governance and Development, 7. pp. 8-15. ISSN 2289-4756

Werner, P., Thorpe, R., \& Bunker, D. (1996). Teaching games for understanding: Evolution of a model. Journal of Physical Education, Recreation and Dance, 67(1), 28-33.

Webb, P. I., \& Pearson, P. J. (2008). An integrated approach to teaching games for understanding (TGFU). Retrieved from http://ro.uow.edu.au/edupapers/52 